\title{
Angiotensin I-converting enzyme polymorphisms, ACE level and blood pressure among Nigerians, Jamaicans and African-Americans
}

\author{
Nourdine Bouzekri ${ }^{1}$, Xiaofeng Zhu ${ }^{2}$, Yanming Jiang ${ }^{2}$, Colin A McKenzie ${ }^{3}$, Amy Luke ${ }^{2}$, \\ Terrence Forrester ${ }^{3}$, Adebowale Adeyemo ${ }^{4}$, Donghui Kan ${ }^{2}$, Martin Farrall ${ }^{5}$, \\ Simon Anderson ${ }^{1}$, Richard S Cooper*,2 and Ryk Ward ${ }^{1}$
}

\footnotetext{
${ }^{1}$ Department of Biological Anthropology, University of Oxford, Oxford, UK; ${ }^{2}$ Department of Preventive Medicine and Epidemiology, Loyola University Medical Center, Maywood, IL, USA; ${ }^{3}$ Tropical Medicine Research Institute, University of the West Indies, Mona, Jamaica; ${ }^{4}$ Department of Pediatrics/Institute for Child Health, College of Medicine, University of Ibadan, Ibadan, Nigeria; ${ }^{5}$ Department of Cardiovascular Medicine, University of Oxford, The Wellcome Trust Centre for Human Genetics, Oxford, UK
}

The genes in the renin-angiotensin system are important physiologic candidates in studies of the genetic susceptibility to hypertension. Limited information has been available in most studies on the extent of variation in the candidate loci or the modifying effects of different environmental settings. We consequently genotyped 13 polymorphisms at the angiotensin I-converting enzyme (ACE) locus at an average distance of $\mathbf{2} \mathrm{kb}$ in $\mathbf{2 7 7 6}$ family members from Nigeria, Jamaica and an African-American community in the US. Allele and haplotype frequencies were similar in the three populations, with modest evidence of European admixture in the US. Two markers were consistently associated with ACE level in the three samples and the proportion of variance accounted for by ACE8 was similar in the three groups. No evidence of consistent association of single markers was noted with blood pressure across the three population samples, however. Likewise, in a haplotype-based analysis, despite significant associations within each population, the findings were not replicated consistently across all three samples. We did observe, however, that the overtransmitted haplotypes among hypertensives were drawn from a single clade, suggesting that susceptibility may cluster in patterns not captured directly by our markers. European Journal of Human Genetics (2004) 12, 460-468. doi:10.1038/sj.ejhg.5201166

Published online 18 February 2004

Keywords: ACE; association; haplotype

\section{Introduction}

Many complex human traits, like blood pressure and glucose regulation, have a large heritable component. However, the molecular variants that shape these phenotypes have not been identified. Genome-wide linkage studies have demon-

*Correspondence: Dr R Cooper, Department of Preventive Medicine and Epidemiology, Loyola University Medical Center, Maywood, IL 60153, USA. Tel: + 1708327 9018; Fax: + 1708327 9009;

E-mail: rcooper@lumc.edu

Received 10 July 2003; revised 16 December 2003; accepted 23 December 2003 strated only modest consistency and few physiologic candidate genes have been well validated. ${ }^{1-4}$

In an effort to reduce complexity, model physiologic systems with well-characterized intermediate phenotypes have been used. The renin-angiotensin system (RAS) is known to have a key role in blood pressure regulation, and numerous studies have explored the impact of variation in the underlying genes on circulating protein levels and blood pressure. For angiotensin I-converting enzyme (ACE), for example, the relationship to blood pressure or other cardiovascular outcomes in the large number of 
published association studies using single markers has been inconsistent. ${ }^{5-9}$ However, linkage analyses and studies with more extensive genotype information have suggested that at least for blood pressure molecular variants in the ACE gene or nearby genes may influence the phenotype of interest. ${ }^{10-13}$ Recently, Zhu et $a l^{14}$ genotyped 10 polymorphisms in the ACE gene in African-Americans and European-Americans. Haplotype analysis suggested a significant association of ACE polymorphisms to hypertension. As the complex nature of the genetic variation at these loci is better appreciated, and more efficient genotyping methods are developed, it may become possible to account more fully for the extensive allelic heterogeneity that is present.

Marked differences in the risk of high blood pressure are observed among human populations, including those who share a common genetic background. ${ }^{15,16}$ Most hypertension studies carried out to date have had very limited ability to incorporate these effects into the analytic design. To obtain more information about the conditioning effect of the environmental setting, we have been conducting parallel population-based family studies among Nigerians, Jamaicans and African-Americans. ${ }^{15}$ Within this framework, we set out to refine our understanding of the potential role of genetic variation at ACE on blood pressure by generating an extensive marker set on the studied family members and measuring the ACE phenotype.

\section{Methods}

\section{Subject recruitment}

The sampling frame for this study was provided by the International Collaborative Study on Hypertension in Blacks, as described in detail elsewhere. ${ }^{15,17,18}$ In this analysis, we used data from 1158 participants from Nigeria who belonged to 312 families; in Jamaica 546 individuals were enrolled from 136 families; in the US 1080 participants belonged to 312 African-American families. No participants reported consistent treatment for hypertension in Nigeria. In Jamaica, 64 participants reported taking antihypertensive medications at the time of the screening examination, while this number was 208 in the US. Study protocols were reviewed and approved by the review boards of the participating institutions. Screenees with elevated blood pressure in Nigeria were referred for treatment. The Nigerian family sample was the subject of previous reports based on a subset of marker data. ${ }^{19}$

Determination of ACE concentration was performed using a previously published sandwich ELISA ${ }^{20}$ with some modifications. Genetic polymorphisms were determined as described previously. ${ }^{13,19}$

\section{Statistical methods}

Allele frequencies in the three population samples were estimated from the founders by the counting method.
Hardy-Weinberg equilibrium at each locus was assessed by the $\chi^{2}$ test with one degree of freedom. ${ }^{21}$ Pairwise linkage disequilibrium (LD) was computed for the three samples using $D^{\prime 22}$ and $r^{2}$ based on the inferred haplotype frequencies from unrelated founders by PHASE. ${ }^{23}$ The statistical significance of a pairwise LD of the markers was accessed by $\chi^{2}$ test. $^{21}$ Individual haplotypes were inferred from the MERLIN program ${ }^{24}$ and the haplotype frequencies were estimated by maximizing the likelihood function over all the possible haplotypes using FUGUE. ${ }^{24}$

For ACE level, measured genotype analysis accounting for familial aggregation and covariate effects was carried out using the computer program ASSOC available in the Statistical Analysis for Genetic Epidemiology (SAGE) package. $^{25-27}$ The backward selection method was used to select the polymorphisms best accounted for the ACE variation in the three population samples separately.

For hypertension, because the numbers of individuals taking antihypertensive drugs were about 19 and 12\% in the US and the Jamaican samples, respectively, a binary trait was used instead. We defined an individual as hypertensive if he/she was treated with antihypertensive drugs, or if he/she was untreated and his/her residual of systolic blood pressure or diastolic blood pressure after adjusting for sex, age and BMI belonged to the upper 25\% of the residual distribution in the nontreated group.

Since admixture exists in the Jamaican and the US samples, the transmission/disequilibrium test (TDT) method is more suitable for these data. We used the generalized TDT for multiple markers proposed by Clayton ${ }^{28}$ and implemented in the computer program TRANSMIT to perform association of hypertension and ACE polymorphisms. The significance level, indicated by $P$-values, is assessed by a bootstrap procedure based on 10000 replicates. For multiple polymorphisms, TRANSMIT reconstructs haplotypes via an E-M algorithm and tests individual haplotype as well as overall transmission distortion.

\section{Results \\ Descriptive characteristics}

A total of 2784 individuals were studied in the three populations. Given the recruitment strategy that targeted high-risk probands, and the lack of consistent treatment at baseline, mean blood pressures were higher in Nigeria than either of the other two samples. Mean ACE levels were also higher in Nigeria $(P<0.05$ when comparing with US or Jamaica). No consistent intercorrelations were noted between blood pressure and ACE. Table 1 presents the distributions of the relevant phenotypes. Non-normality was observed in ACE levels in Nigeria and the US and we used the inverse of the normal cumulative distribution function to transform the values of ACE levels in our subsequent data analysis. General heritability for 
Table 1 Descriptive statistics of the study sample

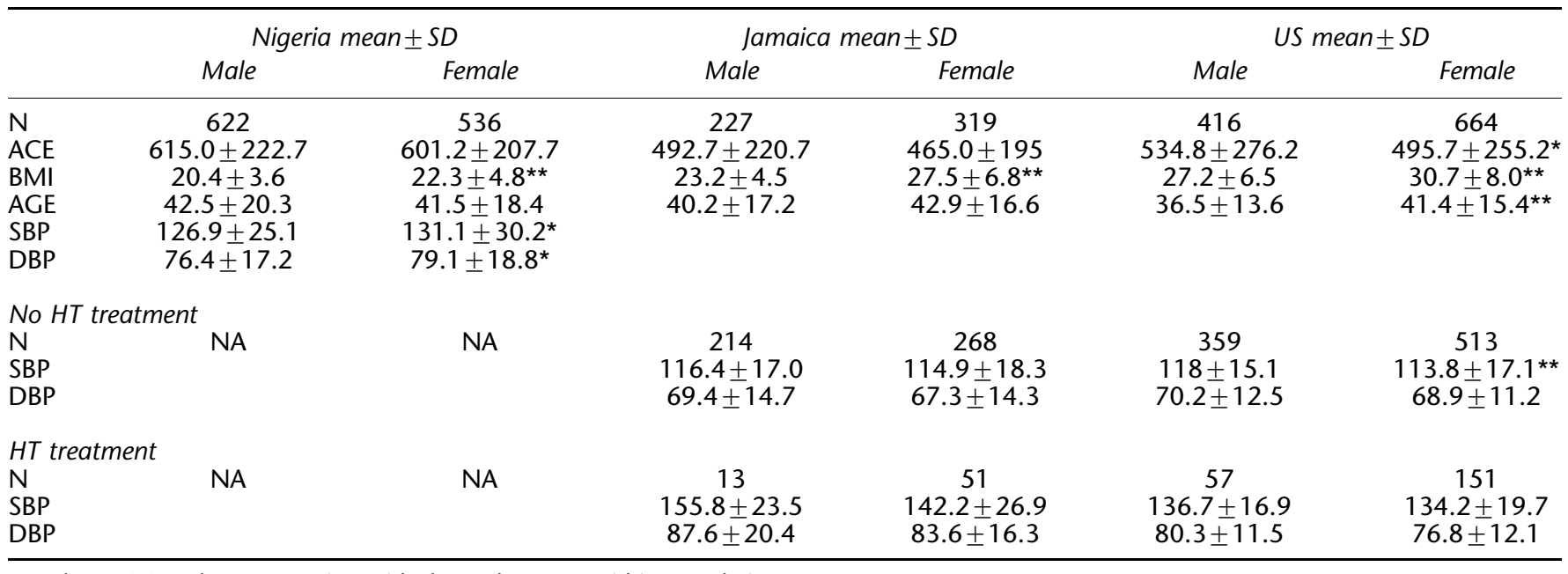

${ }^{\star} P$-value $<0.05$ when comparing with the male group within populations.

${ }^{* *} P$-value $<0.001$ when comparing with the male group within populations.

Table 2 Minor allele frequencies of the ACE polymorphisms and association to ACE plasma level in the three populations

\begin{tabular}{|c|c|c|c|c|c|c|c|}
\hline \multirow[b]{2}{*}{ Marker } & \multirow[b]{2}{*}{ Minor allele } & \multicolumn{2}{|c|}{ Nigeria } & \multicolumn{2}{|c|}{ Jamaica } & \multicolumn{2}{|c|}{ US } \\
\hline & & Freq (\%) & P-value & Freq $(\%)$ & P-value & Freq (\%) & P-value \\
\hline ACE1 & $\mathrm{C}(\mathrm{C} / \mathrm{T})$ & 34.46 & $1.88 \times 10^{-12}$ & 39.65 & $1.4 \times 10^{-4}$ & 33.09 & 0.1 \\
\hline ACE2 & $C(A / C)$ & 34.22 & $2.46 \times 10^{-13}$ & 37.17 & $1.4 \times 10^{-3}$ & 32.16 & 0.043 \\
\hline ACE3 & $\mathrm{T}(\mathrm{C} / \mathrm{T})$ & 5.91 & $6.52 \times 10^{-3}$ & 11.96 & 0.32 & 17.40 & 1.0 \\
\hline ACE4 & $\mathrm{T}(\mathrm{A} / \mathrm{T})$ & 33.23 & $3.33 \times 10^{-16}$ & 39.34 & $9.6 \times 10^{-4}$ & 32.56 & 0.40 \\
\hline ACE5 & $C(C / T)$ & 5.98 & 0.074 & 12.92 & $4.8 \times 10^{-4}$ & 10.97 & $3.63 \times 10^{-10}$ \\
\hline ACEs12 & $\mathrm{C}(\mathrm{C} / \mathrm{T})$ & 8.15 & 0.094 & 7.89 & 0.29 & 7.73 & 0.27 \\
\hline ACEs11 & $\mathrm{A}(\mathrm{A} / \mathrm{G})$ & 3.88 & 0.014 & 9.41 & $4.59 \times 10^{-6}$ & 9.01 & $6.55 \times 10^{-14}$ \\
\hline ACE6 & $\mathrm{T}(\mathrm{C} / \mathrm{T})$ & 9.48 & 0.86 & 16.49 & 0.038 & 18.30 & 0.04 \\
\hline NewACE6 & $G(A / G)$ & 0.61 & 0.22 & 0.50 & 0.44 & 0.25 & 1.0 \\
\hline ACE7 & $\mathrm{G}(\mathrm{A} / \mathrm{G})$ & 36.61 & $3.33 \times 10^{-16}$ & 39.11 & $3.17 \times 10^{-8}$ & 40.55 & $1.01 \times 10^{-11}$ \\
\hline I/D & I(I/D) & 35.74 & $2.22 \times 10^{-16}$ & 38.13 & $1.39 \times 10^{-8}$ & 38.60 & $3.13 \times 10^{-9}$ \\
\hline ACE8 & $G(A / G)$ & 21.24 & 0 & 24.60 & $5.55 \times 10^{-16}$ & 20.37 & 0 \\
\hline ACE9 & $2(2 / 3)$ & 43.71 & $1.8 \times 10^{-4}$ & 42.74 & 0.4 & 41.28 & 0.53 \\
\hline
\end{tabular}

Allele frequencies were estimated using counting method from the extended founders with 492 in Nigeria, 204 in Jamaica and 414 in Maywood, respectively.

ACE - estimated as familial aggregation - was $0.69,0.36$ and 0.56 for the Nigerian, Jamaican and US families, respectively. Exclusion of all persons treated with antihypertensive medications resulted in hereditability for ACE of 0.33 in Jamaica and 0.56 in the US.

\section{Allele/haplotype frequencies and patterns of LD}

In all, 13 markers were typed at the ACE locus (Table 2) and their positions are indicated in Zhu et al. ${ }^{13}$ The minor allele frequencies in the three populations were similar, with the exception of ACE3 and ACE5. The minor alleles of ACE3 and ACE5 are much more frequent in Europeans ${ }^{29}$ and this result most likely represents population admixture in Jamaica and the US.
Using all 13 polymorphisms, common haplotypes (ie frequency $>1.5 \%$ in at least one population) were constructed (Table 3); this set of haplotypes accounted for 74,62 and $68 \%$ of chromosomes in the Nigerian, Jamaican and US samples, respectively. Haplotype frequencies were similar in the three populations, with greater correspondence between the frequencies found in Jamaicans and African-Americans with the Nigerians, again reflecting modest European admixture. Haplotypes TAIA3 and CTDG2 formed by the five SNPs, ACE3, ACE4, insertion/deletion (I/D), ACE8 and ACE9 correspond to the sets of haplotypes \#9 and \#13, and \#12 and \#15, respectively. TAIA3 and CTDG2 were found to be more frequent in a French population sample $(31 \text { and } 33 \%)^{30}$ than observed in our Nigerian 
Table 3 Four clade haplotype frequencies of the ACE gene in the three populations

\begin{tabular}{|c|c|c|c|c|c|c|c|c|c|c|c|c|c|c|c|c|}
\hline & ACE1 & ACE2 & $A C E 3$ & ACE4 & ACE5 & ACEs 21 & ACEs 11 & ACE6 & NewACE6 & $A C E 7$ & $I / D$ & ACE8 & ACE9 & Nigeria & Jamaica & US \\
\hline \multicolumn{17}{|c|}{ Clade 1} \\
\hline 1 & $\mathrm{~T}$ & A & C & A & $\mathrm{T}$ & $\mathbf{T}$ & G & C & A & A & D & A & 2 & 12.86 & 7.98 & 10.30 \\
\hline 2 & $\mathrm{~T}$ & A & C & A & $\mathrm{T}$ & $\mathbf{T}$ & G & C & A & A & D & A & 3 & 12.79 & 10.79 & 11.93 \\
\hline 3 & $\mathrm{~T}$ & A & C & A & $\mathrm{T}$ & $\mathbf{T}$ & G & C & A & A & D & G & 3 & 10.36 & 6.22 & 6.36 \\
\hline 6 & $\mathrm{~T}$ & A & C & A & $\mathrm{T}$ & T & G & C & A & A & D & G & 2 & 5.75 & 2.98 & 3.93 \\
\hline 7 & $\mathrm{~T}$ & A & C & A & $\mathrm{T}$ & C & G & C & A & A & D & A & 3 & 3.42 & 3.78 & 3.2 \\
\hline 14 & $\mathrm{~T}$ & A & C & $T$ & $\mathrm{~T}$ & $\mathbf{T}$ & G & $\mathrm{C}$ & A & $A$ & D & A & 2 & - & 1.99 & 0.67 \\
\hline \multicolumn{17}{|c|}{ Clade 2} \\
\hline 4 & C & C & C & $\mathrm{T}$ & $\mathrm{T}$ & T & G & C & A & G & I & A & 2 & 9.66 & 7.9 & 7.13 \\
\hline 5 & C & C & C & $\mathrm{T}$ & $\mathrm{T}$ & $T$ & G & C & A & G & 1 & A & 3 & 7.74 & 5.48 & 4.12 \\
\hline 11 & C & $\mathrm{C}$ & C & $\mathrm{T}$ & $\mathrm{T}$ & $\mathrm{C}$ & G & C & A & G & I & A & 3 & 1.7 & 0.56 & 0.33 \\
\hline \multicolumn{17}{|c|}{ Clade 3} \\
\hline 8 & $\mathbf{T}$ & A & C & A & $\mathrm{T}$ & $\mathrm{T}$ & G & C & A & G & I & A & 3 & 2.47 & 2.99 & 3.35 \\
\hline 9 & C & A & $\mathrm{T}$ & A & $\mathrm{T}$ & $\mathrm{T}$ & G & $\mathbf{T}$ & A & G & 1 & A & 3 & 2.2 & 2.42 & 2.00 \\
\hline 10 & $\mathbf{T}$ & C & C & A & $\mathrm{T}$ & $\mathrm{T}$ & G & $\mathrm{T}$ & A & G & I & A & 3 & 2.14 & 0.45 & 1.93 \\
\hline 13 & $\mathbf{T}$ & A & $\mathrm{T}$ & A & $\mathrm{T}$ & $\mathrm{T}$ & G & $\mathbf{T}$ & A & G & 1 & A & 3 & 1.53 & 3.28 & 7.96 \\
\hline \multicolumn{17}{|c|}{ Clade 4} \\
\hline 12 & C & C & C & $\mathrm{T}$ & C & $\mathrm{T}$ & A & C & A & A & D & G & 2 & 1.61 & 4.51 & 6.05 \\
\hline 15 & C & A & C & $\mathrm{T}$ & C & $\mathrm{T}$ & $A$ & C & A & A & D & G & 2 & - & 1.57 & 0.42 \\
\hline
\end{tabular}

Bold letters indicate the difference in haplotypes within a clade. - , indicate haplotype frequency $<1 \%$.

sample (3.73 and 1.61\%). Both TAIA3 and CTDG2 were more frequent in the Jamaican and US samples than in the Nigerian sample (5.70 and 6.08\% in Jamaicans, and 9.96 and $6.47 \%$ the US samples). A putative haplotype tree was constructed from the 15 haplotypes using the principal of maximum parsimony found in the software PAUP, ${ }^{31}$ and the evolutionary relationships among these haplotypes are described in Figure 1. The haplotypes were then grouped into four clades according to the Templeton's algorithm. ${ }^{32,33}$ As noted, the I/D polymorphism connects clade (I, IV) and (II, III).

The pattern of LD measured by $D^{\prime}$ and $r^{2}$ among the 13 markers was calculated among the unrelated individuals in each of the three population samples (Tables 4-6). With the exception of very low-frequency SNPs (eg NewACE6), there was a general correspondence in the pattern across the three groups. The average pairwise correlation for each of the $D^{\prime}$ values between the groups was 0.86 in Nigerians vs Jamaicans, 0.84 in Jamaicans vs African-Americans and 0.76 in Nigerians vs African-Americans. Using the haplotype block definition of Zhu et al, ${ }^{34}$ the only common block identified across three populations consists of ACE7, I/D and ACE8 $\left(D^{\prime} \geqslant 0.89\right)$. Presumably, due to the SNPs with minor allele frequencies less than $20 \%$, we did not identify additional blocks. ACE1, ACE2, ACE4, ACE7 and I/D were found to be in significant LD in all three samples. In the US sample, two more markers, viz, ACE3 and ACE9, were also in significant LD with this set of SNPs. More striking, however, was the virtual absence of blocks where $D^{\prime}>0.9$. The other region of moderately high LD involved SNPs $1-4$. This impression was confirmed by an analysis based

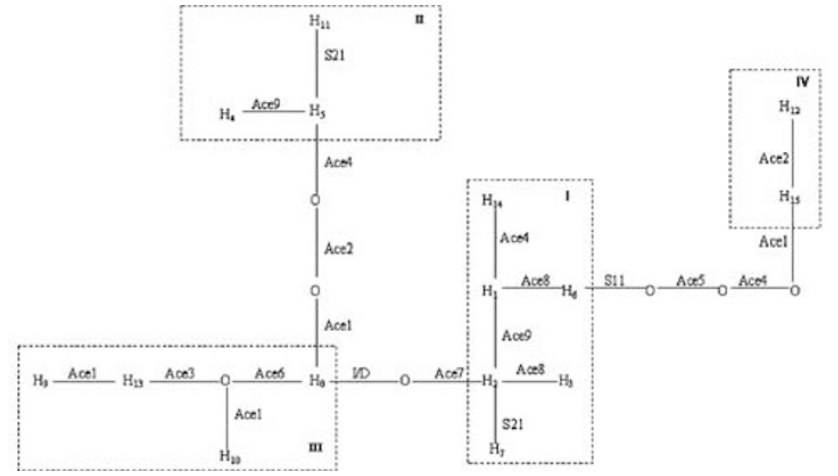

Figure 1 Cladogram of the ACE gene derived from multilocus haplotypes.

on other haplotype block definitions currently in $\mathrm{use}^{35}$ virtually no blocks were identified that included more than two SNPs and many SNPs could not be placed in blocks at all. $^{36}$

\section{Association of ACE polymorphisms with ACE concentration}

The association of each polymorphism with ACE levels was tested using the likelihood statistic with the adjustment of age, gender and BMI (Table 2). Since ACE level and medication treatment is only significantly correlated in Maywood sample, we also adjusted medication treatment in the analysis of Maywood sample. The largest effect was localized to ACE8 for all three population samples; the proportion of total variance in plasma ACE explained by 
Table 4 Pairwise LD of polymorphisms in the ACE gene in the Nigerian sample $\left(D^{\prime}\right.$ and $\left.r^{2}\right)$

\begin{tabular}{|c|c|c|c|c|c|c|c|c|c|c|c|c|}
\hline & Ace1 & Ace2 & Ace 3 & Ace4 & Ace5 & Aces 12 & Aces 11 & Ace6 & NewAce6 & Ace7 & $I / D$ & Ace8 \\
\hline ACE2 & $\begin{array}{l}0.79 \\
0.61\end{array}$ & & & & & & & & & & & \\
\hline ACE3 & $\begin{array}{l}0.06 \\
0\end{array}$ & $\begin{array}{l}0.88 \\
0.02\end{array}$ & & & & & & & & & & \\
\hline ACE4 & $\begin{array}{l}0.86 \\
0.70\end{array}$ & $\begin{array}{l}0.76 \\
0.56\end{array}$ & $\begin{array}{l}0.89 \\
0.02\end{array}$ & & & & & & & & & \\
\hline ACE5 & $\begin{array}{l}0.99 \\
0.12\end{array}$ & $\begin{array}{l}0.84 \\
0.09\end{array}$ & $\begin{array}{l}0.88 \\
0\end{array}$ & $\begin{array}{l}0.71 \\
0.06\end{array}$ & & & & & & & & \\
\hline ACEs12 & $\begin{array}{l}0.62 \\
0.02\end{array}$ & $\begin{array}{l}0.49 \\
0.01\end{array}$ & $\begin{array}{l}1.00 \\
0.01\end{array}$ & $\begin{array}{l}0.60 \\
0.01\end{array}$ & $\begin{array}{l}0.89 \\
0\end{array}$ & & & & & & & \\
\hline ACEs11 & $\begin{array}{l}0.92 \\
0.06\end{array}$ & $\begin{array}{l}0.84 \\
0.06\end{array}$ & $\begin{array}{l}0.83 \\
0\end{array}$ & $\begin{array}{l}0.55 \\
0.02\end{array}$ & $\begin{array}{l}0.74 \\
0.35\end{array}$ & $\begin{array}{l}0.87 \\
0\end{array}$ & & & & & & \\
\hline ACE6 & $\begin{array}{l}0.20 \\
0\end{array}$ & $\begin{array}{l}0.13 \\
0\end{array}$ & $\begin{array}{l}0.85 \\
0.43\end{array}$ & $\begin{array}{l}0.72 \\
0.03\end{array}$ & $\begin{array}{l}1.00 \\
0.01\end{array}$ & $\begin{array}{l}0.77 \\
0.01\end{array}$ & $\begin{array}{l}1.00 \\
0\end{array}$ & & & & & \\
\hline NewACE6 & $\begin{array}{l}0.99 \\
0\end{array}$ & $\begin{array}{l}0.98 \\
0\end{array}$ & $\begin{array}{l}0.94 \\
0\end{array}$ & $\begin{array}{l}0.99 \\
0\end{array}$ & $\begin{array}{l}1.00 \\
0\end{array}$ & $\begin{array}{l}1.00 \\
0\end{array}$ & $\begin{array}{l}1.00 \\
0\end{array}$ & $\begin{array}{l}1.00 \\
0\end{array}$ & & & & \\
\hline ACE7 & $\begin{array}{l}0.63 \\
0.36\end{array}$ & $\begin{array}{l}0.56 \\
0.28\end{array}$ & $\begin{array}{l}0.85 \\
0.08\end{array}$ & $\begin{array}{l}0.58 \\
0.29\end{array}$ & $\begin{array}{l}0.49 \\
0.01\end{array}$ & $\begin{array}{l}0.25 \\
0\end{array}$ & $\begin{array}{l}0.76 \\
0.01\end{array}$ & $\begin{array}{l}0.70 \\
0.09\end{array}$ & $\begin{array}{l}0.99 \\
0\end{array}$ & & & \\
\hline I/D & $\begin{array}{l}0.62 \\
0.35\end{array}$ & $\begin{array}{l}0.55 \\
0.27\end{array}$ & $\begin{array}{l}0.80 \\
0.07\end{array}$ & $\begin{array}{l}0.57 \\
0.29\end{array}$ & $\begin{array}{l}0.48 \\
0.01\end{array}$ & $\begin{array}{l}0.38 \\
0.01\end{array}$ & $\begin{array}{l}0.77 \\
0.01\end{array}$ & $\begin{array}{l}0.66 \\
0.08\end{array}$ & $\begin{array}{l}0.99 \\
0\end{array}$ & $\begin{array}{l}0.95 \\
0.88\end{array}$ & & \\
\hline ACE8 & $\begin{array}{l}0.68 \\
0.06\end{array}$ & $\begin{array}{l}0.60 \\
0.05\end{array}$ & $\begin{array}{l}0.97 \\
0.02\end{array}$ & $\begin{array}{l}0.68 \\
0.06\end{array}$ & $\begin{array}{l}0.15 \\
0\end{array}$ & $\begin{array}{l}0.57 \\
0.01\end{array}$ & $\begin{array}{l}0.49 \\
0.04\end{array}$ & $\begin{array}{l}0.65 \\
0.01\end{array}$ & $\begin{array}{l}0.98 \\
0\end{array}$ & $\begin{array}{l}0.99 \\
0.15\end{array}$ & $\begin{array}{l}1.00 \\
0.15\end{array}$ & \\
\hline ACE9 & $\begin{array}{l}0.15 \\
0.02\end{array}$ & $\begin{array}{l}0.13 \\
0.01\end{array}$ & $\begin{array}{l}0.87 \\
0.04\end{array}$ & $\begin{array}{l}0.16 \\
0.02\end{array}$ & $\begin{array}{l}0.48 \\
0.02\end{array}$ & $\begin{array}{l}0.38 \\
0.01\end{array}$ & $\begin{array}{l}0.29 \\
0\end{array}$ & $\begin{array}{l}0.67 \\
0.04\end{array}$ & $\begin{array}{l}0.97 \\
0.01\end{array}$ & $\begin{array}{l}0.08 \\
0\end{array}$ & $\begin{array}{l}0.08 \\
0\end{array}$ & $\begin{array}{l}0.08 \\
0\end{array}$ \\
\hline
\end{tabular}

LD with $P$-values $<0.0006$ indicated in bold. $D^{\prime}$ is at upper of $r^{2}$ in each cell.

Table 5 Pairwise LD of polymorphisms in the ACE gene in the Jamaican sample $\left(D^{\prime}\right.$ and $\left.r^{2}\right)$

\begin{tabular}{|c|c|c|c|c|c|c|c|c|c|c|c|c|}
\hline & Ace1 & Ace2 & Ace3 & Ace 4 & Ace 5 & Aces 12 & Aces 11 & Ace6 & NewAce6 & Ace7 & $I / D$ & Aces \\
\hline ACE2 & $\begin{array}{l}0.69 \\
0.43\end{array}$ & & & & & & & & & & & \\
\hline \multirow[t]{2}{*}{ ACE3 } & 0.11 & 0.73 & & & & & & & & & & \\
\hline & 0 & 0.04 & & & & & & & & & & \\
\hline \multirow[t]{2}{*}{ ACE4 } & 0.80 & 0.71 & 0.81 & & & & & & & & & \\
\hline & 0.62 & 0.44 & 0.06 & & & & & & & & & \\
\hline \multirow[t]{2}{*}{ ACE5 } & 0.96 & 0.72 & 0.83 & 0.98 & & & & & & & & \\
\hline & 0.19 & 0.12 & 0.01 & 0.19 & & & & & & & & \\
\hline \multirow[t]{2}{*}{ ACEs12 } & 0.92 & 0.91 & 0.50 & 0.92 & 0.86 & & & & & & & \\
\hline & 0.05 & 0.04 & 0 & 0.05 & 0.01 & & & & & & & \\
\hline \multirow[t]{2}{*}{ ACEs11 } & 0.95 & 0.64 & 0.37 & 0.90 & 0.93 & 0.80 & & & & & & \\
\hline & 0.14 & 0.07 & 0 & 0.12 & 0.67 & 0.01 & & & & & & \\
\hline \multirow[t]{2}{*}{ ACE6 } & 0.32 & 0.43 & 0.70 & 0.69 & 0.99 & 0.93 & 0.99 & & & & & \\
\hline & 0.01 & 0.02 & 0.36 & 0.06 & 0.02 & 0.01 & 0.02 & & & & & \\
\hline \multirow[t]{2}{*}{ NewACE6 } & 0.43 & 0.41 & 1.00 & 0.44 & 0.12 & 1.00 & 0.17 & 1.00 & & & & \\
\hline & 0 & 0 & 0 & 0 & 0 & 0 & 0 & 0 & & & & \\
\hline \multirow[t]{2}{*}{ ACE7 } & 0.42 & 0.36 & 0.64 & 0.33 & 0.61 & 0.68 & 0.85 & 0.62 & 0.29 & & & \\
\hline & 0.18 & 0.12 & 0.09 & 0.11 & 0.03 & 0.02 & 0.05 & 0.11 & 0 & & & \\
\hline \multirow[t]{2}{*}{ I/D } & 0.39 & 0.32 & 0.65 & 0.30 & 0.73 & 0.68 & 0.88 & 0.67 & 0.28 & 0.94 & & \\
\hline & 0.15 & 0.10 & 0.09 & 0.08 & 0.04 & 0.02 & 0.05 & 0.13 & 0 & 0.84 & & \\
\hline \multirow[t]{2}{*}{ ACE8 } & 0.06 & 0.08 & 0.46 & 0.09 & 0.57 & 0.03 & 0.79 & 0.73 & 0.01 & 0.89 & 0.89 & \\
\hline & 0 & 0 & 0.01 & 0 & 0.14 & 0 & 0.21 & 0.03 & 0 & 0.16 & 0.15 & \\
\hline \multirow[t]{2}{*}{ ACE9 } & 0.28 & 0.26 & 0.83 & 0.43 & 0.66 & 0.68 & 0.98 & 0.68 & 0.10 & 0.14 & 0.17 & 0.20 \\
\hline & 0.07 & 0.06 & 0.07 & 0.16 & 0.08 & 0.03 & 0.13 & 0.06 & 0 & 0.01 & 0.01 & 0.02 \\
\hline
\end{tabular}

LD with $P$-values $<0.0006$ indicated in bold. $D^{\prime}$ is at upper of $r^{2}$ in each cell.

this polymorphism was 21, 17 and $14 \%$ in Nigeria, Jamaica and the US, respectively. To identify the best overall models from each of the three populations, we performed backward model selection (Table 7). Only ACE8 and ACE9 were retained in common in the three models; polymorphisms in the $5^{\prime}$ region were also significant in the three best models but no polymorphisms from that region were common in all three population samples. 
Table 6 Pairwise LD of polymorphisms in the ACE gene in the US African-American sample $\left(D^{\prime}\right.$ and $\left.r^{2}\right)$

\begin{tabular}{|c|c|c|c|c|c|c|c|c|c|c|c|c|}
\hline & Ace 1 & Ace2 & Ace3 & Ace 4 & Ace5 & Aces 12 & Aces 11 & Ace6 & NewAce6 & Ace7 & $I / D$ & Ace8 \\
\hline ACE2 & $\begin{array}{l}0.79 \\
0.60\end{array}$ & & & & & & & & & & & \\
\hline \multirow[t]{2}{*}{ ACE3 } & 0.47 & 0.92 & & & & & & & & & & \\
\hline & 0.02 & 0.08 & & & & & & & & & & \\
\hline \multirow[t]{2}{*}{ ACE4 } & 0.84 & 0.76 & 0.92 & & & & & & & & & \\
\hline & 0.69 & 0.56 & 0.08 & & & & & & & & & \\
\hline \multirow{2}{*}{ ACE5 } & 0.89 & 0.71 & 0.89 & 0.88 & & & & & & & & \\
\hline & 0.20 & 0.14 & 0.02 & 0.02 & & & & & & & & \\
\hline \multirow[t]{2}{*}{ ACEs12 } & 0.81 & 0.82 & 0.99 & 0.91 & 0.82 & & & & & & & \\
\hline & 0.02 & 0.02 & 0.01 & 0.03 & 0.01 & & & & & & & \\
\hline \multirow[t]{2}{*}{ ACEs11 } & 0.97 & 0.75 & 0.87 & 0.87 & 0.95 & 1.00 & & & & & & \\
\hline & 0.19 & 0.12 & 0.02 & 0.16 & 0.72 & 0.01 & & & & & & \\
\hline \multirow[t]{2}{*}{ ACE6 } & 0.44 & 0.51 & 0.75 & 0.86 & 0.93 & 0.65 & 0.92 & & & & & \\
\hline & 0.02 & 0.03 & 0.53 & 0.08 & 0.02 & 0.01 & 0.02 & & & & & \\
\hline \multirow[t]{2}{*}{ NewACE6 } & 0.76 & 0.76 & 1.00 & 0.76 & 1.00 & 1.00 & 1.00 & 1.00 & & & & \\
\hline & 0 & 0 & 0 & 0 & 0 & 0 & 0 & 0 & & & & \\
\hline \multirow[t]{2}{*}{ ACE7 } & 0.83 & 0.34 & 0.71 & 0.27 & 0.65 & 0.50 & 0.90 & 0.81 & 0.73 & & & \\
\hline & 0.10 & 0.08 & 0.15 & 0.05 & 0.04 & 0.01 & 0.06 & 0.20 & 0 & & & \\
\hline \multirow[t]{2}{*}{ I/D } & 0.33 & 0.31 & 0.64 & 0.24 & 0.64 & 0.44 & 0.90 & 0.74 & 0.74 & 0.90 & & \\
\hline & 0.08 & 0.07 & 0.13 & 0.04 & 0.03 & 0.01 & 0.05 & 0.18 & 0 & 0.78 & & \\
\hline \multirow[t]{2}{*}{ ACE8 } & 0.11 & 0.06 & 0.40 & 0.09 & 0.65 & 0.98 & 0.89 & 0.82 & 1.00 & 0.96 & 0.96 & \\
\hline & 0.01 & 0 & 0.01 & 0 & 0.21 & 0.02 & 0.31 & 0.04 & 0 & 0.16 & 0.16 & \\
\hline \multirow[t]{2}{*}{ ACE9 } & 0.38 & 0.33 & 0.70 & 0.41 & 0.57 & 0.56 & 0.77 & 0.87 & 0.73 & 0.24 & 0.27 & 0.36 \\
\hline & 0.10 & 0.07 & 0.07 & 0.12 & 0.06 & 0.01 & 0.09 & 0.11 & 0 & 0.03 & 0.03 & 0.05 \\
\hline
\end{tabular}

LD with $P$-values $<0.0006$ indicated in bold. $D^{\prime}$ is at upper of $r^{2}$ in each cell.

Table 7 Best models to fit ACE polymorphisms and plasma level in the three populations

\begin{tabular}{|c|c|c|c|c|c|c|c|c|}
\hline \multirow{2}{*}{$\begin{array}{l}\text { Nigeria } \\
\text { Marker in model }\end{array}$} & \multirow[b]{2}{*}{$\beta^{b}(s t d)$} & \multirow[b]{2}{*}{ P-value } & \multicolumn{3}{|c|}{ lamaica } & \multicolumn{3}{|c|}{$U S^{a}$} \\
\hline & & & Marker in model & $\beta^{\mathrm{b}}(s t d)$ & P-value & Marker in model & $\beta^{b}(s t d)$ & P-value \\
\hline $\begin{array}{l}\text { ACE3 } \\
\text { ACE4 } \\
\text { ACE5 } \\
\text { ACEs1.2 } \\
\text { ACE8 } \\
\text { ACE9 }\end{array}$ & $\begin{array}{r}-0.25(0.085) \\
-0.22(0.047) \\
0.23(0.086) \\
0.29(0.076) \\
-0.80(0.053) \\
-0.14(0.041)\end{array}$ & $\begin{array}{l}0.003 \\
210^{-6} \\
0.007 \\
1.410^{-4} \\
0.0 \\
5.610^{-4}\end{array}$ & $\begin{array}{l}\text { ACE1 } \\
\text { ACE3 } \\
\text { ACEs1.1 } \\
\text { ACE6 } \\
\text { ACE8 } \\
\text { ACE9 }\end{array}$ & $\begin{array}{r}-0.30(0.077) \\
-0.31(0.130) \\
-0.51(0.149) \\
0.26(0.128) \\
-0.61(0.094) \\
-0.29(0.074)\end{array}$ & $\begin{array}{l}1.210^{-4} \\
0.018 \\
6.610^{-4} \\
0.044 \\
5.6610^{-11} \\
7.210^{-5}\end{array}$ & $\begin{array}{l}\text { ACE2 } \\
\text { ACEs1.2 } \\
\text { ACEs1.1 } \\
\text { ACE8 } \\
\text { ACE9 }\end{array}$ & $\begin{array}{c}-0.18(0.06) \\
0.21(0.097) \\
-0.43(0.112) \\
-0.47(0.074) \\
-0.11(0.052)\end{array}$ & $\begin{array}{l}0.003 \\
0.030 \\
1.410^{-4} \\
1.910^{-10} \\
0.028\end{array}$ \\
\hline
\end{tabular}

${ }^{a}$ Only the US African-American sample was adjusted with hypertensive medication.

${ }^{\mathrm{b}}$ The estimators of linear regression coefficients and an additive model is assumed for all the SNPs.

\section{Association with hypertension}

In a test of association of each individual SNP with hypertension, only ACE9 in the Jamaicans and ACE3, ACE6 and ACE9 in the African-Americans were in significant transmission distortion $(P<0.05)$. Owing to the potential biological link of ACE level with blood pressure, we also examined the association of blood pressure/hypertension with the polymorphisms identified by modeling ACE level. Since multilocus haplotypes may be in strong LD with a functional variant, providing more power to detect the association, we performed haplotype analysis using TRANSMIT in each of the population samples separately using the backward model selection strategy. We began by including the polymorphisms in the final models determined for the prediction of
ACE plasma levels (Table 7), supplemented with those that showed marginal significance $(P<0.2)$ in the single locus association analysis for hypertension. At each step, we dropped one polymorphism if the pair of haplotype effects due to this polymorphism on hypertension was consistent, in the sense that any pair of haplotypes distinguished by this polymorphism were both overtransmitted or both undertransmitted, or the frequency of one of the haplotypes was low. This procedure is equivalent to selecting the model with the largest global test statistic and the smallest number of polymorphisms.

Table 8 presents the final models for each of the three population samples. As noted previously, no associated polymorphisms were common across the three population 
samples. In the Nigerian sample, ACE6, ACE7 and I/D were included in the final model (global test $P$-value 0.007). Haplotype CAD was transmitted more often than expected under the null hypothesis $(P=0.007)$. ACE7 and I/D are in strong LD where they always appear in the major haplotypes AD or GI. When we used only the ACE6 and I/D polymorphisms, the global test was still significant $(P=0.019)$. In the Jamaican sample, ACEs12 and ACE9 were in the final model (global test $P=0.046$ ). Haplotype T2 was overtransmitted in the hypertensive offspring $(P=0.025)$, while T3 was undertransmitted $(P=0.0055)$. ACE1, ACE3 and ACE5 formed the final model for the US sample (global test $P=0.0002$ ) and haplotype TCT was significantly overtransmitted in the hypertensive offspring $(P<0.0001)$. Although no polymorphisms were found in common in the three final models, all the overtransmitted haplotypes (ie CAD in the Nigerians, most of T2 in the Jamaicans and TCT in the US) belong to clade I; all three of these haplotypes were more likely to be transmitted to the affected offspring. This result could indicate an underlying consistency in the three populations if one assumes that unobserved effects could be attributed to these chromosomes. Finally, we pooled the three samples together for TDT analysis retaining polymorphisms ACE1, ACE3, ACE5, ACE6 ACE7, I/D, ACEs12 and ACE9. Using the same strategy, we obtained a final model including ACE1, ACE3, ACE5, ACE6 and I/D with a global test $P$-value 0.007. Haplotype TCTCD was significantly overtransmitted to the affected offspring and this haplotype again belongs to clade I.

Table 8 Final models fitting ACE haplotypes to hypertension status in the three population samples (analysis based on TRANSMIT)

\begin{tabular}{|c|c|c|c|c|}
\hline Haplotype freq & Obs\# & Exp\# & $T D T$ & P-value \\
\hline \multicolumn{5}{|c|}{ Nigeria, ACE6-ACE7-I/D } \\
\hline TGI & 44.5 & 44.5 & 0 & 1.0 \\
\hline CGI & 138.6 & 149.1 & 3.1 & 0.086 \\
\hline CAD & 328.6 & 311.8 & 6.7 & 0.007 \\
\hline Global test & & & & 0.007 \\
\hline \multicolumn{5}{|c|}{ Jamaica, ACEs12-ACE9 } \\
\hline T3 & 136.6 & 149.5 & 7.4 & 0.0055 \\
\hline C3 & 23.6 & 20.3 & 1.9 & 0.1166 \\
\hline T2 & 144.9 & 135.1 & 4.8 & 0.025 \\
\hline Global test & & & & 0.045 \\
\hline \multicolumn{5}{|c|}{ US, ACE1-ACE3-ACE5 } \\
\hline TTT & 85.4 & 94.5 & 3.2 & 0.05 \\
\hline TCT & 408.3 & 378.6 & 16.3 & 0.0 \\
\hline CCT & 125.7 & 136.4 & 3.2 & 0.068 \\
\hline $\mathrm{CCC}$ & 76.9 & 79.2 & 0.2 & 0.59 \\
\hline Global test & & & & 0.0002 \\
\hline
\end{tabular}

$P$-values were estimated based on 10000 bootstrap samples

\section{Discussion}

ACE is a key component of the RAS that converts angiotensin into a vasoactive compound that leads to the constriction of resistance blood vessels and retention of salt and water, thereby influencing both short- and long-term blood pressure regulation. ACE level has been known to be highly heritable for a number of years, and the strong underlying genotype-phenotype relationship has made it an important test system in which to examine the complexities of quantitative traits. The ACE gene has consequently been intensely studied as a susceptibility gene for hypertension. Linkage was found at ACE or a nearby locus in the Framingham Heart Study on two occasions, although restricted to men. ${ }^{10,11,36}$ Among previous studies of the ACE I/D polymorphism with hypertension, a variety of studies have suggested that an association exists ${ }^{5-7,37-43}$ while others have produced negative results. ${ }^{8,9,44-46}$ The conflicting association results with the I/D polymorphism further imply that a single marker may not include sufficient information.

In this analysis, we accumulated a total of 36000 genotypes across the $25 \mathrm{~kb}$ region of this gene in 2776 individuals. While power declined in the TDT analyses that restricted the family units, we had considerable information about the segregating variability at this locus. Our association analysis between ACE plasma level and ACE polymorphisms suggests that there is more than one functional variant affecting ACE plasma level across the three populations. ACE 8 and ACE9 are always present in the final models for the three populations, suggesting that ACE8 alone does not summarize all the variation residing in $3^{\prime}$ section of the gene. The effect of the $3^{\prime}$ SNPs was not explained fully by ACE8 in all the samples, confirming a role for variants from at least two loci within this gene. ${ }^{13,24,47}$ This pattern was described in greater detail in an earlier publication using a set of 35 markers in the ACE gene in a subset of our Nigerian family members, as well as in an independent sample of Jamaicans. ${ }^{19,47}$ In the Nigerian analysis, polymorphism ACE 22982, located at the $3^{\prime}$ end of the gene, was apparently more influential than ACE8. All the final models in the current analysis include the $5^{\prime}$ polymorphisms, confirming the presence of an additional functional variant. Even with the relatively strong genotype-phenotype relationship between ACE genetic variants and the plasma level, and a robust data set, it is still difficult to define the precise variants responsible for the phenotypic variation. At the very least, these results indicate that association studies of quantitative traits should be highly consistent across different populations, conditional on an effect of the variant on a phenotype that is large enough and adequate sample size.

The effect of the ACE polymorphisms on hypertension if such an effect indeed exists - may be much more complex than that observed for ACE level. In our single locus TDT analysis, we observed a nominally significant 
association with hypertension for ACE9 in Jamaicans and ACE3 and ACE6 in the US; no markers were associated among the Nigerians. Adjustment for multiple testing would eliminate any associations beyond chance for the individual polymorphisms. Further analysis of multilocus haplotypes suggested that different combinations of ACE polymorphisms were associated with hypertension in each of the three populations. Cladistic analysis, however, demonstrated that the haplotypes associated with the increasing risk of hypertension did mainly fall into a single clade. This result is consistent with the finding in an earlier study of African-Americans and European-Americans, ${ }^{14}$ where the risk haplotype belonged to the clade I. This result suggests that multiple variants in the ACE gene that influence risk of hypertension may have become embedded in specific phylogenetic branches over the course of its evolutionary history.

We previously performed association analysis relating blood pressure and ACE polymorphisms in the Nigerian sample and identified that a two-locus epistasis model (ACE4 and ACE8) provided the best fit to blood pressure variation. ${ }^{13}$ However, in the current analysis we found that haplotype CAD, consisting of ACE6, ACE7 and I/D, is significantly overtransmitted to hypertensive offspring. There are several possible explanations as to why we found different patterns using the two approaches: (1) The findings in both analyses could be due to chance. However, the Nigerian result is consistent with previous results in African-Americans and European-Americans. ${ }^{14,43}$ (2) ACE4, ACE6, ACE7, I/D and ACE8 are in significant LD, and ACE7, I/D and ACE8 fall into a single haplotype block. The physical linkage among these SNPs makes it more difficult to sort out the separate identity of the causal variants.

Against a similar genetic background, African-Americans experience higher rates of hypertension than Nigerians. While it is evident that environmental exposures therefore influence the expression of the genetic trait, it is not known whether that effect is differential across environments (ie reflects gene-environment interactions). This study demonstrates little or no gene-environment interaction related to ACE level; however, given the very weak association with hypertension, it is impossible to know whether heterogeneity across the study populations is purely chance, or the conditioning effect of the environment. Other practical aspects, such as use of antihypertensive medication in the US, made it difficult to conduct analyses that were entirely consistent across groups.

A description of the patterns of genetic variation that underlie complex quantitative traits continues to elude genetic epidemiologists. In this analysis, we have confirmed that two loci in the ACE gene influence the circulating level of the enzyme, however, we could not isolate any single DNA site; if that pattern is the norm, then dissection of the genetic background for candidate genes will have to be carried out in great detail. Despite a large study sample and extensive genetic information, the evidence for an association with hypertension remains uncertain. If one assumes that the resolving power for blood pressure is an order of magnitude less than for ACE level, given the anticipated small influence of this locus, then it might be reasonable to argue that the search process could not go lower than identification of an association with an entire clade. It must then follow that if causal variants can only be localized to clades, then the search process becomes even more difficult than generally anticipated.

\section{Acknowledgements}

We acknowledge the substantial support of The Wellcome Trust Centre for Human Genetics under the direction of GM Lathrop, and the provision of genotyping facilities and assistance by $R$ Cox and his laboratory, especially the work of Alison Hughill. Partial support for this project was also provided by an internal grant from the University of Oxford, and by grants from the NHLBI (HL45508; HL 47910), NIGMS (GM28356) and NCRR(RR03655). We thank the residents of Igbo-Ora, Nigeria, Spanish Town, Jamaica and Maywood, IL, USA for their willing participation in this research project.

\section{References}

1 Krushkal J, Ferrell R, Mockrin SC, Turner ST, Sing CF, Boerwinkle E: Genome-wide linkage analyses of systolic blood pressure using highly discordant siblings. Circulation 1999; 99: 1407-1410.

2 Lohmueller KE, Pearce CL, Pike M, Lander ES, Hirschhorn JN: Meta-analysis of genetic association studies supports a contribution of common variants to susceptibility to common disease. Nat Genet 2003; 33: 177-182.

$3 \mathrm{Xu} \mathrm{X}$, Rogus JJ, Terwedow HA et al: An extreme-sib-pair genome scan for genes regulating blood pressure. Am J Hum Genet 1999; 64: $1694-1701$

4 Rice T, Rankinen T, Province MA et al: Genome-wide linkage analysis of systolic and diastolic blood pressure: the Quebec Family Study. Circulation 2000; 102: 1956-1963.

5 Mastana S, Nunn J: Angiotensin-converting enzyme deletion polymorphism is associated with hypertension in a Sikh population. Hum Hered 1997; 47: 250-253.

6 Chiang FT, Chern TH, Lai ZP et al: Age- and gender-dependent association of the angiotensin-converting enzyme gene with essential hypertension in a Chinese population. J Hum Hypertens 1996; 10: 823-826.

7 Keavney B, McKenzie C, Parish S et al: Large-scale test of hypothesised associations between the angiotensin-convertingenzyme insertion/deletion polymorphism and myocardial infarction in about 5000 cases and 6000 controls. International Studies of Infarct Survival (ISIS) Collaborators. Lancet 2000; 355: $434-442$.

8 Tamaki S, Nakamura Y, Tsujita Y et al: Polymorphism of the angiotensin converting enzyme gene and blood pressure in a Japanese general population (the Shigaraki Study). Hypertens Res 2002; 25: 843-848.

$9 \mathrm{Gu}$ XX, Spaepen M, Guo C et al: Lack of association between the I/D polymorphism of the angiotensin-converting enzyme gene and essential hypertension in a Belgian population. I Hum Hypertens 1994; 8: 683-685.

10 O'Donnell CJ, Lindpaintner K, Larson MG et al: Evidence for association and genetic linkage of the angiotensin-converting enzyme locus with hypertension and blood pressure in men but 
not women in the Framingham Heart Study. Circulation 1998; 97: $1766-1772$.

11 Fornage M, Amos CI, Kardia S, Sing CF, Turner ST, Boerwinkle E: Variation in the region of the angiotensin-converting enzyme gene influences interindividual differences in blood pressure levels in young white males. Circulation 1998; 97: 1773-1779.

12 Baima J, Nicolaou M, Schwartz F et al: Evidence for linkage between essential hypertension and a putative locus on human chromosome 17. Hypertension 1999; 34: 4-7.

13 Zhu X, Bouzekri N, Southam L et al: Linkage and association analysis of angiotensin I-converting enzyme (ACE)-gene polymorphisms with ACE concentration and blood pressure. Am J Hum Genet 2001; 68: 1139-1148.

14 Zhu X, Chang C, Yan D et al: Associations between hypertension and genetic variants in the genes of the renin-angiotensin system. Hypertension 2003; 41: 1027-1034.

15 Cooper R, Rotimi C, Ataman S et al: The prevalence of hypertension in seven populations of west African origin. Am J Public Health 1997; 87: 160-168.

16 Wolf-Maier K, Cooper RS, Banegas JR et al: Hypertension prevalence and blood pressure levels in 6 European countries, Canada, and the United States. JAMA 2003; 289: 2363-2369.

17 Rotimi CN, Cooper RS, Cao G et al: Maximum-likelihood generalized heritability estimate for blood pressure in Nigerian families. Hypertension 1999; 33: 874-878.

18 Guo X, Rotimi C, Cooper R et al: Evidence of a major gene effect for angiotensinogen among Nigerians. Ann Hum Genet 1999; 63: 293-300.

19 Cox R, Bouzekri N, Martin S et al: Angiotensin-1-converting enzyme (ACE) plasma concentration is influenced by multiple ACE-linked quantitative trait nucleotides. Hum Mol Genet 2002; 11: 2969-2977.

20 Danilov S, Savoie F, Lenoir B et al: Development of enzyme-linked immunoassays for human angiotensin I converting enzyme suitable for large-scale studies. J Hypertens 1996; 14: 719-727.

21 Weir B: Genetic Data Analysis II. Sunderland, MA: Sinauer Associates; 1996.

22 Lewontin R: The interactions of selection and linkage. I. General considerations; heterotic models. Genetics 1964; 49: 49-67.

23 Stephens JC, Schneider JA, Tanguay DA et al: Haplotype variation and linkage disequilibrium in 313 human genes. Science 2001; 293: $489-493$

24 Abecasis GR, Cherny SS, Cookson WO, Cardon LR: Merlin - rapid analysis of dense genetic maps using sparse gene flow trees. Nat Genet 2002; 30: 97-101.

25 Phillips MS, Lawrence R, Sachidanandam R et al: Chromosomewide distribution of haplotype blocks and the role of recombination hot spots. Nat Genet 2003; 33: 382-387.

26 SAGE: Statistical Analysis for Genetic Epidemiology, Release 4.0. Cleveland, OH: Department of Epidemiology and Biostatistics, Rammelkamp Center for Education and Research, MetroHealth Campus, Case Western Reserve University; 2000.

27 George VT, Elston RC: Testing the association between polymorphic markers and quantitative traits in pedigrees. Genet Epidemiol 1987; 4: 193-201.

28 Clayton D: A generalization of the transmission/disequilibrium test for uncertain-haplotype transmission. Am J Hum Genet 1999; 65: $1170-1177$.

29 Villard E, Tiret L, Visvikis S, Rakotovao R, Cambien F, Soubrier F: Identification of new polymorphisms of the angiotensin Iconverting enzyme (ACE) gene, and study of their relationship to plasma ACE levels by two-QTL segregation-linkage analysis. Am J Hum Genet 1996; 58: 1268-1278.

30 Soubrier F, Martin S, Alonso A et al: High-resolution genetic mapping of the ACE-linked QTL influencing circulating ACE activity. Eur J Hum Genet 2002; 10: 553-561.
31 Swofford DL, Waddell PJ, Huelsenbeck JP, Foster PG, Lewis PO, Rogers JS: Bias in phylogenetic estimation and its relevance to the choice between parsimony and likelihood methods. Syst Biol 2001; 50: 525-539.

32 Templeton AR, Boerwinkle E, Sing CF: A cladistic analysis of phenotypic associations with haplotypes inferred from restriction endonuclease mapping. I. Basic theory and an analysis of alcohol dehydrogenase activity in Drosophila. Genetics 1987; 117: 343-351.

33 Templeton AR, Sing CF, Kessling A, Humphries S: A cladistic analysis of phenotype associations with haplotypes inferred from restriction endonuclease mapping. II. The analysis of natural populations. Genetics 1988; 120: 1145-1154.

34 Zhu X, Zhang S, Kan D, Cooper RS: Haplotype block definition and its application; in Altman RB, Dunker AK, Hunter L, Jung TA, Klein TE (eds): Pacific Symposium on Biocomputing 2004; World Scientific, 2003, pp 152-163.

35 Gabriel SB, Schaffner SF, Nguyen $\mathrm{H}$ et al: The structure of haplotype blocks in the human genome. Science 2002; 296: $2225-2229$.

36 Levy D, DeStefano AL, Larson MG et al: Evidence for a gene influencing blood pressure on chromosome 17. Genome scan linkage results for longitudinal blood pressure phenotypes in subjects from the Framingham Heart Study. Hypertension 2000; 36: $477-483$.

37 Fernandez-Llama P, Poch E, Oriola J et al: Angiotensin converting enzyme gene I/D polymorphism in essential hypertension and nephroangiosclerosis. Kidney Int 1998; 53: 1743-1747.

38 Vassilikioti S, Doumas M, Douma S et al: Angiotensin converting enzyme gene polymorphism is not related to essential hypertension in a Greek population. Am J Hypertens 1996; 9: $700-702$.

39 Duru K, Farrow S, Wang JM, Lockette W, Kurtz T: Frequency of a deletion polymorphism in the gene for angiotensin converting enzyme is increased in African-Americans with hypertension. Am J Hypertens 1994; 7: 759-762.

40 Morise T, Takeuchi Y, Takeda R: Angiotensin-converting enzyme polymorphism and essential hypertension. Lancet 1994; 343 125.

41 Schmidt S, van Hooft IM, Grobbee DE, Ganten D, Ritz E: Polymorphism of the angiotensin I converting enzyme gene is apparently not related to high blood pressure: Dutch Hypertension and Offspring Study. J Hypertens 1993; 11: $345-348$.

42 Harrap SB, Davidson HR, Connor JM et al: The angiotensin converting enzyme gene and predisposition to high blood pressure. Hypertension 1993; 21: 455-460.

43 Zee RY, Lou YK, Griffiths LR, Morris BJ: Association of a polymorphism of the angiotensin I-converting enzyme gene with essential hypertension. Biochem Biophys Res Commun 1992; 184: 9-15.

44 Vasku A, Soucek M, Znojil V et al: Angiotensin I-converting enzyme and angiotensinogen gene interaction and prediction of essential hypertension. Kidney Int 1998; 53: 1479-1482.

45 Sugiyama T, Morita H, Kato N, Kurihara H, Yamori Y, Yazaki Y: Lack of sex-specific effects on the association between angiotensin-converting enzyme gene polymorphism and hypertension in Japanese. Hypertens Res 1999; 22: $55-59$.

46 Barley J, Blackwood A, Miller $\mathrm{M}$ et al: Angiotensin converting enzyme gene I/D polymorphism, blood pressure and the renninangiotensin system in Caucasian and Afro-Caribbean peoples. $J$ Hum Hypertens 1996; 10: 31-35.

47 Zhu X, McKenzie CA, Forrester T et al: Localization of a small genomic region associated with elevated ACE. Am J Hum Genet 2000; 67: 1144-1153. 